\title{
UNDERPLANTING OF YOUNG COCONUTS UNDER ADULT STANDS OF COCONUT PALMS FOR PRODUCTION OF EDIBLE VEGETATIVE PITH OR 'UBOD'
}

\author{
By \\ Gerardo D. Padrones ${ }^{1}$, Millicent I. Secretaria ${ }^{1}$ \& \\ Severino S. Magat ${ }^{2 *}$
}

\begin{abstract}
The feasibility and viability of producing edible vegetative coconut pith or 'ubod' from young coconuts planted with double plants per hill under adult coconut bearing palms was studied at the Philippine Coconut Authority - Davao Research Center, Bago Oshiro Davao City.

The average weight of 'ubod' from double planting scheme was $5.9 \mathrm{~kg} / \mathrm{palm}$ (range 2.8 -9.4 $\mathrm{kg}$ ) on the first year of 'ubod' harvest. There was a very slight increase (average of $0.2 \mathrm{~kg} / \mathrm{palm}$ ) in 'ubod' weight on the second year of harvest. The total ubod yield for two years harvesting schedule was $8.9 \mathrm{t} / \mathrm{ha}$.

Under the Davao growing condition, cost and return analysis of 'ubod' production in double plants per hill scheme indicated a total net income of P129,030 per ha in 4 years with a return on investment (ROI) of $180 \%$. While copra production from adult bearing palms realized a total of $\mathrm{P}$ 114,675 for 4 years with an average ROI of $242 \%$. Considering copra plus 'ubod' yield from this production scheme, the cumulative net income and ROI obtained were: P 242,389.6 and 203\% respectively.

Based on the results of this study with modest fertilizer application of ammonium sulfate plus common salt $(\mathrm{NaCl})$, underplanting of two young coconuts per hill (spaced at two feet away from each other) at $3 \times 3 \mathrm{~m}$ distance between spaces of bearing coconut palms harvested at three years from field-planting is a profitable and viable production scheme to increase farm productivity. The farm income with this coconut-based production is increased by $200 \%$ compared to coconut monocropping.
\end{abstract}

\section{INTRODUCTION}

The coconut palm is known as the 'tree of life' because of its diversified products and byproducts that support the human life. Aside from the main product of coconut i.e. copra/oil production which supports one third of the country's population, the coconut tree provides many other useful food and non-food by-products. One new food item which has become popular in the recent years is the edible coconut vegetative pith or 'ubod'. This food item commands a considerable price in the market today because of its many uses in food making, e.g. fresh lumpia or eggroll, pickled 'ubod', chicken 'ubod' salad, 'chopsuey' and other food preparations in domestic homes and even in first class restaurants and hotels. With the present modern food processing facilities, this terminal bud or coconut cabbage could be preserved (canned or bottled) and can be marketed locally and internationally as a food delicacy. Thampan (1975) referred to this preserved food item as a 'millionaire's salad'.

With the need for R \& D on sustainable coconut farming, a research study on planting young palms under bearing coconut palms for 'ubod' or pith production was undertaken. This

\footnotetext{
${ }^{1}$ Science Research Specialist II, Agronomy \& Soils Division, PCA-DRC Bago- Oshiro Davao City, Philippines.

${ }^{2}$ Senior Scientist \& program Leader Crop Agronomy, Nutrition \& Farming Systems, PCA, Department of Agriculture, Quezon City, Philippines.
} 
system/strategy provides an alternative source of coconut pith or 'ubod' thus, preventing the indiscriminate cutting of existing productive coconut palms for such food purpose. An earlier study on the production of 'ubod' was done by Protacio and Ruanes (1997) by planting coconut seedlings at close planting in an open area following a sorjan system of planting and harvesting them after two to three years. They found out that there was no significant difference in 'ubod' weight from trees harvested at year two and year three after field planting but the number of harvestable trees was higher at year three. Furthermore, they recommended selective harvesting at two years when 20 to $25 \%$ of the crop may be ready to harvest.

This study was undertaken at the Philippine Coconut Authority - Davao Research Center, Bago Oshiro, Davao City with the aim of assessing the feasibility of planting young coconuts (two plants per hill) under bearing palms for 'ubod' or pith production and determining the economics of this production strategy.

\section{MATERIALS AND METHODS}

Experimental site

The study was conducted at the Davao Research Center in a Tugbok clay loam reddish brown residual soil (Tropudalf soil taxonomy) with good external and internal drainage. The area has an elevation ranging from 120 to $140 \mathrm{~m}$ above sea level. Benchmark soil analysis showed an average $\mathrm{pH}$ of 6.5, 5.3 m.e. exchangeable $\mathrm{Mg} / 100 \mathrm{~g}$ soil, 0.45 m.e. $\mathrm{K}, 11.4 \mathrm{~m}$. e Ca., 0.08 m.e. $\mathrm{Na}$ and $68 \%$ base saturation.

\section{Experimental material}

'Laguna' tall (LAGT) seedlings were used as underplants under bearing LAGT palms aged 25 years planted at a distance of $9 \times 9 \mathrm{~m}$ triangular system.

Methodology

The young coconuts/seedlings (aged six months old) were transplanted in the field under bearing palms. Two seedlings were planted per hill (spaced at two feet from each other) in a $3 \times 3 \mathrm{~m}$ triangular system at the interspaces of bearing coconut palms, and about two meters away from the row of coconut palms.

\section{Cultural Management}

All palms in each plot were circle weeded, within the root zone every two months. The area was kept free of cover crops since spaces between main crops were planted to young palms. Both the full bearing palms and the young intercrops palm were applied with mineral fertilizers (ammonium sulfate and $\mathrm{NaCl}$ ) in broadcast-fork-in method at $2 \mathrm{~m}$ around the base of the palms and incorporated with soil. Double rates of fertilizers were applied in double plants per hill. At young stage of seedlings when pest and disease occurred, spraying of chemical was done.

\section{Harvesting of 'ubod' from young coconuts}

At three years from field planting, when palms have developed a bole, began to form a trunk and the girth at the base of the stem at least $100 \mathrm{~cm}$, young palms were harvested for 'ubod' production. With these indexes, selective harvesting was done leaving behind the smaller palms for the next's year harvesting. The actual field harvesting of 'ubod' included the following steps (Fig.1): Fig 1. 


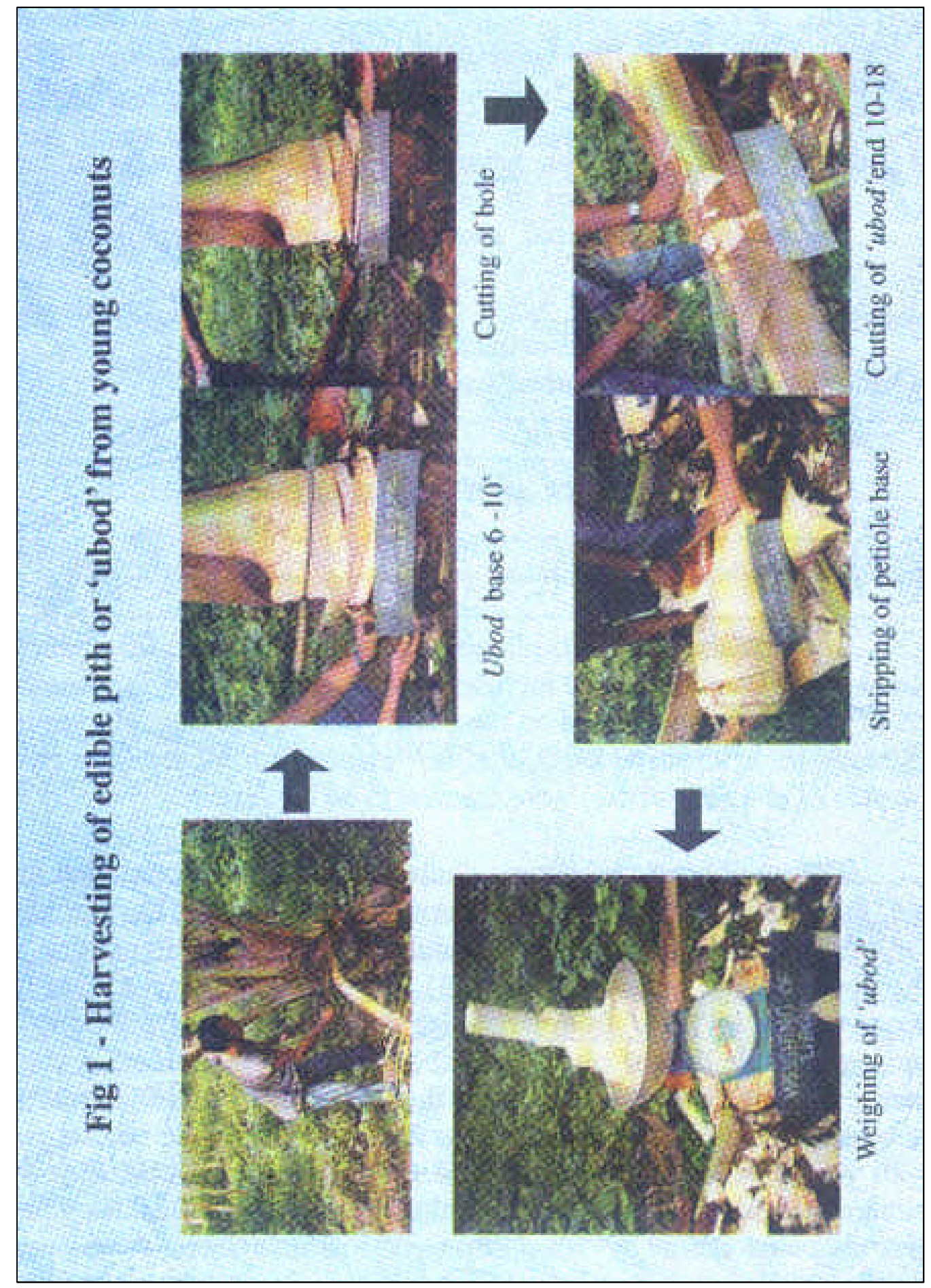

1) Select young palms with bigger bole (girth size of $100 \mathrm{~cm}$ or more);

2) Trim/cut with a bolo few older leaves to avoid obstruction during bole cutting;

3) Cut the bole of harvestable palms at 6-10 inches below 'ubod' base and about 10-18 inches above the 'ubod' end. Longer cut beyond the 'ubod' end ensured protection from early spoilage after harvest;

4) Remove outer covering of 'ubod' by striping the base of petiole until 'ubod' (soft portion) is extracted; and

5) Determine the weight of 'ubod' using a weighing scale. 


\section{RESULTS AND DISCUSSION}

\section{'Ubod' production}

Three years after field planting of the underplants, fifty percent of total plants were harvested for 'ubod' production (Figure 1). Another 50\% of palms were harvested on the fourth year of planting. Harvesting was made on a selective basis, that is, plants with bigger bole (with girth size of at least $100 \mathrm{~cm}$ ) were the first to be harvested.

The $u b o d$ produced from double planting were classified into large, medium and small sizes and were weighed (Table 1). The girth size (bole) of harvested young palms and length of ' $u b o d$ ' in relation to size were likewise measured (Table 2). It could be observed that the average weight of 'ubod' from large size did not increase from third to fourth year while that of medium and small sizes manifested a slight increase in their 'ubod' weight from first to second year of harvesting. These results indicated that there is no need to wait for the second year for all young palms to be harvested since the palms have reached the optimum weight and length for a profitable net return. Besides young palms are better source of 'ubod' than older palms (Cinco; Pugoy pers. communication, 1997).

This result was corollary to that of Protacio and Ruanes (1995) except that their first year of harvesting 'ubod' was two years from planting and distance of planting young coconuts in open field was much closer to each other ( 1 x $1 \mathrm{~m}$ square). In our present planting distance, the smaller palms were allowed to grow bigger due to more space despite two plants per hill. Hence, heavier and longer 'ubod' were produced.

Table 1. Average fresh weight of per palm at $3^{\text {rd }}$ and $4^{\text {th }}$ year from planting

\begin{tabular}{|l|c|c|c|}
\hline \multicolumn{1}{|c|}{ Classification } & At $3^{\text {rd }}$ year & At $4^{\text {th }}$ year & Average \\
\hline & \multicolumn{3}{|c|}{$($ In kg) } \\
\hline Large & 9,9 & 8.8 & 9.4 \\
\hline Medium & 5.7 & 6.1 & 5.9 \\
\hline Small & 2.1 & 3.5 & 2.8 \\
\hline Average & 5.9 & 6.1 & 6.0 \\
\hline
\end{tabular}

Table 2. Girth size (bole) of harvested young palms and length of fresh ubod in relation to its sizes

\begin{tabular}{|l|c|c|c|}
\hline \multirow{2}{*}{ Particular } & \multicolumn{3}{|c|}{ Classification } \\
\cline { 2 - 4 } & Large & Medium & Small \\
\hline Girth $(\mathrm{cm})$ & 96.0 & 88.5 & 84.4 \\
\hline Length $(\mathrm{cm})$ & 28.1 & 25.1 & 22.3 \\
\hline
\end{tabular}

\section{Economic analysis}

\section{a) 'Ubod' production}

Under double planting scheme, young underplants showed a total 'ubod' yield of 4,377.8 and $4,526.2 \mathrm{~kg} / \mathrm{ha}$ on the first and second year of harvest (third and fourth year from planting). While there was no yield of 'ubod' on the 1st and 2nd year of planting, the net income from third and 
fourth year could compensate for the net loss incurred on the previous year (Table 3). Hence, the cumulative 'ubod' yield was 8.9 tons per ha for two years and a total net income of P129,030 for four years with an average return on investment (ROI) of $180 \%$.

Table 3. Cost and return analysis of "ubod" production per hectare from young coconuts.

\begin{tabular}{|l|r|r|r|r|r|r|}
\hline \multirow{2}{*}{ Year } & Ubod & \multicolumn{1}{c|}{$\begin{array}{c}\text { Yield } \\
\text { /ha }\end{array}$} & \multicolumn{1}{c|}{ Gross } & Total & $\begin{array}{c}\text { Net } \\
\text { Income }\end{array}$ & ROI $^{4}$ \\
\cline { 2 - 7 } & Yield/palm & & Income $^{3}$ & \multicolumn{1}{c|}{ Cost } & (Net/Loss $)$ & \\
\cline { 2 - 7 } & $(\mathrm{kg})$ & $(\mathrm{kg})$ & $(\mathrm{P})$ & $(\mathrm{P})$ & $(\mathrm{P})$ & $(\%)$ \\
\hline 1 & - & - & - & 29,550 & $(29,550)$ & \\
3 & - & - & - & 12,628 & $(12,628)$ & \\
4 & $5.9^{1}$ & $4,377.8$ & 87,556 & 19,127 & 68,429 & \\
Total & $6.1^{2}$ & $4,526.2$ & 113,155 & 10,376 & 102,779 & \\
Average & 12.0 & $8,904.0$ & 200,711 & 71,681 & 129,030 & \\
\hline
\end{tabular}

${ }^{1}$ Average yield of $u b o d /$ tree $\left(3^{\text {rd }} \mathrm{yr}\right)$

${ }^{2}$ Average yield of $u b o d /$ tree $\left(4^{\text {th }} \mathrm{yr}\right)$

${ }^{3}$ Ubod price $-\mathrm{P} 20 / \mathrm{kg}-3^{\text {rd }} \mathrm{yr} \mathrm{P} 25 / \mathrm{kg}-4^{\text {th }}$ yr

${ }^{4}$ Return on investment

\section{b) Copra production}

A positive return on investment was obtained for four years from copra production from bearing palms (Table 4). Higher net income could be observed from third to fourth year from planting of young coconuts (almost doubled the first and second). This is most possibly due to the double dosage of fertilization in young coconuts wherein the roots of bearing palms could have absorbed more nutrients from nearby double fertilized seedlings in one hill. Subsequently, higher ROI of $242 \%$ was noted for bearing coconut with young double plants.

Table 4. Cost and return analysis of copra production of bearing palms.

\begin{tabular}{|c|c|c|c|c|c|c|}
\hline \multirow{2}{*}{ Year } & Copra ${ }^{1}$ & Ubod & Gross & Total & Net Income & $\mathrm{ROI}^{2}$ \\
\hline & $\begin{array}{c}\text { Yield/ } \\
\text { Palm (kg) }\end{array}$ & $\begin{array}{c}\text { Yield/ha } \\
(\mathrm{kg})\end{array}$ & $\begin{array}{l}\text { Income } \\
(\mathrm{P})\end{array}$ & $\begin{array}{l}\text { Cost } \\
\text { (P) }\end{array}$ & $\begin{array}{c}\text { (Net Loss) } \\
(\mathrm{P})\end{array}$ & $\%$ \\
\hline 1 & 26.4 & $3,775.2$ & $30,201.6$ & $13,411.0$ & 16,791 & 125 \\
\hline 2 & 22.6 & $3,231.8$ & $32,318.0$ & $10,902.0$ & 21,416 & 196 \\
\hline 3 & 27.9 & $3,989.7$ & $43,886.7$ & $10,577.0$ & 33,310 & 315 \\
\hline 4 & 26.2 & $3,746.6$ & $56,199.0$ & 13.040 .0 & 43,159 & 331 \\
\hline Total & 103.1 & $14,743.3$ & $162,605.3$ & $47,930.0$ & 114,675 & \\
\hline Average & 25.8 & $3,685.8$ & $40,651.3$ & $11,982.5$ & 28,669 & 242 \\
\hline
\end{tabular}

${ }^{1}$ Copra price per kg: $1^{\text {st }} \mathrm{r}-\mathrm{P} 8.00 ; 2^{\text {nd }} \mathrm{yr}-\mathrm{P} 10.00 ; 3^{\text {rd }} \mathrm{yr}-\mathrm{P} 11.004^{\text {th }} \mathrm{yr}-\mathrm{P} 15.00$

${ }^{2}$ Return on investment 


\section{c) Cumulative copra and 'ubod' production}

Cost and return analysis for combined copra and 'ubod' production from bearing and young coconuts, respectively revealed an encouraging return on investment from this planting scheme (Table 5). Double planting scheme under bearing palms produced an ROI of $203 \%$ which implied that by following this production scheme, a coconut farmer could obtained a net profit twice that of his investment cost after four years. This is assuming that there is an available market for such food item.

Table 5. Cost and return analysis of copra and 'ubod' production of bearing \& young coconuts per hectare.

\begin{tabular}{|l|r|r|r|r|r|r|}
\hline Year & Yield/ ubod & $\begin{array}{c}\text { Ha/ } \\
\text { year } \\
(\mathrm{kg}) \\
\text { Copra }\end{array}$ & $\begin{array}{c}\text { Gross } \\
\text { Income } \\
(\mathrm{P})\end{array}$ & $\begin{array}{c}\text { Total Cost } \\
(\mathrm{P})\end{array}$ & $\begin{array}{c}\text { Net } \\
\text { Income/ } \\
\text { (Net Loss) }\end{array}$ & ROI \\
\hline 1 & - & $3,775.2$ & $30,201.6$ & $42,961.0$ & $(14,075.4)$ & \\
2 & - & $3,231.8$ & $32,318.0$ & $23,530.0$ & $8,788.0$ & \\
3 & $4,377.8$ & $3,989.7$ & $131,442.7$ & $29,704.0$ & $101,739.0$ & \\
4 & $4,526.2$ & $3,746.6$ & $169,354.0$ & $23,416.0$ & $145,938.0$ & \\
Total & $8,904.0$ & $14,743.3$ & $363,316.3$ & $119,611.0$ & $242,389.6$ & \\
Average & $4,452.0$ & $3,685.8$ & $90,829.1$ & $29,902.7$ & $60,597.4$ & 203 \\
\hline
\end{tabular}

The higher net income and ROI obtained in double planting could be attributed to better yield of bearing palms brought about by the benefits obtained from double fertilization of young coconuts and to the higher number of palms (1,484 young palms per ha) harvested for 'ubod' production. The detail of cost for ubod and copra production is presented in Annex 1.

\section{CONCLUSION AND RECOMMENDATION}

Planting of young coconuts with double plants per hill in a $3 \times 3 \mathrm{~m}$ triangular system under bearing coconut palms is a feasible and profitable production strategy that could augment the income of coconut farmers. High net income from 'ubod' per hectare could be produced from double planting scheme due to its higher planting density. Furthermore, coconut bearing palms benefited more due to more nutrient absorption from double planting, thus cumulatively, produced higher net income and ROI.

Based on the results of this study with modest fertilizer application of ammonium sulfate plus $\mathrm{NaCl}$, planting two young coconut palms/hill under coconut bearing palms for $u b o d$ production is a profitable and viable production scheme to increase coconut farm productivity. The best time to harvest coconut palms for 'ubod' production is on the third year from planting. There is no need to wait for another year to harvest all palms for this food purpose.

This production strategy offers an alternative source of producing coconut pith without cutting our existing productive coconut palms. This could contribute to the conservation of natural resources such as coconut trees, thereby maintaining the natural balance of the ecosystem. Likewise, with the increasing demand for this food item in our growing population, it is best to try this production scheme in old existing bearing coconut palms. The planting scheme used for the underpants can also be utilized in replanting old existing palms with some remaining young coconuts arranged in a $9 \times 9 \mathrm{~m}$ triangular planting distance. 


\section{ACKNOWLEDGEMENT}

The authors wish to express their sincere gratitude to the staff of the Davao Research Center with special mention to the labor force of the Agronomy and Soils Division (ASD) for their genuine support in the field activities of this study, to Mr. Rogaciano Z. Margate, Chief, ASD, PCA-DRC for his constructive comments and suggestion for the improvement of this paper, and Mr. Romero C. Blancaver, Manager, PCA- DRC and Mr. Carlos B. Carpio, Deputy Administrator for Agricultural Research and Development Branch, PCA for their concern and support to this research undertaking.

Above all to our ALMIGHTY GOD for without HIM, we, the authors can do nothing.

\section{REFERENCES}

CINCO, O.L. 1997. Personal Communication, as Market of the Bankerohan Vendors Association, Davao City. A prospect of 'ubod' production, younger palms better source than older palm.

PROTACIO, C.M. and D.A. RUANES. 1997. Alternative Production Technology for Coconut 'Ubod'. Proceedings 13th Annual Scientific Conference of the Federation of Crop Science Socie- ties of the Phil (FCSSP). Baguio City, 25-29 May 1997. p.52

PUGOY, R. 1997. Personal Communication ('Ubod' dealer) Bankerohan Vendor Association. Prospect of 'ubod' product; younger palm better source of 'ubod' than older palms.

THAMPAN, P.K. 1975. Minor product of food value. The coconut palm and its product. Green Villa pub. House. p. 302. 
Annex 1. Details of production cost under the economic analysis of:

1. Ubod production of young palms per hectare

Materials

1,484 seednuts +296 (20\%) for replanting (P3.00/seednut)

Cost

14 bags (700g) Ammosul @ P3.90/kg

P 5,340.00

$5,460.00$

14 bags (700g) NaCl (salt)@3.75/kg

$5,250.00$

2 bottles insecticide (P140/bottle)

280.00

knapsack (insecticide sprayer)

$1,070.00$

3 pcs weeding scythe @ 150/pc

450.00

Sub-total $\quad P 17,850.00$

\section{Labor}

No. of mandays Cost

Cleaning of seedbed

Harvesting of seednuts(1500 pcs)

Selection, lay-outing \& setting of seednut

Seedbed maintenance i.e. sanitation

Lay-outing, stick preparation staking

Digging of holes

Planting \& initial fertilization

Maintenance(weeding \& sanitation (3x/year)

Second fertilization (2x/year)

Spraying insecticide

(P90/manday)

360.00

360.00

360.00

1440.00

540.00

3780.00

1080.00

1080.00

2160.00

540.00

Sub-total $\quad P 11,700.00$

Grand total cost (double planting)

P 29,550.00

Year 2

Materials

$1,113 \mathrm{~kg}$ (22.26 bags)ammosul@P3.90/kg

$1068.4 \mathrm{~kg}(21.4)$ table salt @ $3.75 \mathrm{~kg}$

Cost

$4,341.70$

$4,006.50$

10 bottles insecticide P140/bottle)

$1,400.00$

Sub-total

$9,748.20$

\section{Labor}

General weeding \& under brushing (3x/year)

Fertilizer application \& fork-in

No. of mandays

12

12

$1,080.00$

$1,080.00$

8

720.00

Sub-total

$2,880.00$

\section{Year 3}

\section{Materials}

1,484 kg (29.6 kgs)Ammosual @ 4.29/kg

$1,855 \mathrm{~kg}$ (18.6) table salt @ 4.13/kg

$7,661.15$

10 bottles insecticide@140/bottle

$1,260.00$

2 pcs bolo@ $@ 200 / p c$

400.00

2 pcs shovel @ P255/pc 


\section{Labor}

General \& ring weeding $(3 \mathrm{x} / \mathrm{yr})$

Fertilization

Spraying insecticide $(2 \mathrm{x} / \mathrm{yr})$

Ubod cutting (5.8 min/tree@P.19/min)

Grand total cost (double planting)
Man-day

$1,080.00$

360.00

409.55

Sub-total

$2,929.55$

$19,127.06$

\section{Year 4}

\section{Materials}

$935 \mathrm{~kg}$ (18.6bags) Ammosul@P4.29/kg)

1,006 kg (20 bags) NaCI@P4.13/kg

\section{Labor}

General weeding (ring \& under brushing $3 \mathrm{x} / \mathrm{yr}$

Fertilization

Spraying insecticide $1 \mathrm{x} / \mathrm{yr}$

Cutting of ubod (5.8 min/tree@P.19/min)

\section{Sub-total $\quad 8,165.93$}

Man-day

12

$1,080.00$

$\begin{array}{ll}6 & 540.00 \\ 2 & 180.00\end{array}$

409.55

Sub-total $\quad 2,209.55$

\section{Grand total cost (double planting)}

$10,375.48$

2. Copra production of bearing palms per hectare

\section{Materials}

2 sets harvesting poles @P170/set

4.3 bags Ammosul (215 kg) @3.90/kg

4.9 bags(NaCI (243.1 kg)@P3.75/kg

4 pcs scythes for weeding at P180/yr

3 pcs grub hoes for fork in at $\mathrm{P} 180 / \mathrm{pc}$

2 pcs bolos@P180/pc

1 unit weighing scale (25 kg cap)@P1,300

\section{Labor}

General weeding $(3 \mathrm{x} / \mathrm{yr})$

Fertilization $(2 \mathrm{x} / \mathrm{yr})$

No. of Man-day

12

8

Harvesting, hauling \& copra making (20\% of copra value) 


\begin{tabular}{|c|c|c|}
\hline Labor & $\begin{array}{l}\text { No. of mandays } \\
(\mathrm{P} 90 / \text { manday })\end{array}$ & Cost \\
\hline Cleaning of seedbed & 4 & 360.00 \\
\hline Harvesting of seednuts $(1500 \mathrm{pcs})$ & 4 & 360.00 \\
\hline Selection, lay-outing \& setting of seednut & 4 & 360.00 \\
\hline Seedbed maintenance i.e. sanitation & 16 & 1440.00 \\
\hline Lay-outing, stick preparation staking & 6 & 540.00 \\
\hline Digging of holes & 42 & 3780.00 \\
\hline Planting \& initial fertilization & 12 & 1080.00 \\
\hline Maintenance(weeding \& sanitation (3x/year) & 12 & 1080.00 \\
\hline Second fertilization $(2 \mathrm{x} /$ year $)$ & 24 & 2160.00 \\
\hline Spraying insecticide & 6 & 540.00 \\
\hline Sub-total & & $\mathrm{P} 11,700.00$ \\
\hline Grand total cost (double planting & & P 29,550.00 \\
\hline \multicolumn{3}{|l|}{ Year 2} \\
\hline Materials & & Cost \\
\hline 1113 kg (22.26 bags)ammosul@P3.90/kg & & $4,341.70$ \\
\hline $1068.4 \mathrm{~kg}(21.4)$ table salt @ $3.75 \mathrm{~kg}$ & & $4,006.50$ \\
\hline 10 bottles insecticide P140/bottle) & & $1,400.00$ \\
\hline Sub-total & & $9,748.20$ \\
\hline Labor & No. of mandays & \\
\hline General weeding \& under brushing (3x/year) & 12 & $1,080.00$ \\
\hline Fertilizer application \& fork-in & 12 & $1,080.00$ \\
\hline Spraying insecticide & 8 & 720.00 \\
\hline Sub-total & & $2,880.00$ \\
\hline \multirow{2}{*}{\multicolumn{3}{|c|}{$\begin{array}{l}\text { Year } 3 \\
\text { Materials }\end{array}$}} \\
\hline & & \\
\hline 1484 kg (29.6 kgs)Ammosual@4.29/kg & & $6,366.36$ \\
\hline $1855 \mathrm{~kg}(18.6)$ table salt @ $4.13 / \mathrm{kg}$ & & $7,661.15$ \\
\hline 10 bottles insecticide @ 140/bottle & & $1,260.00$ \\
\hline 2 pcs bolo@ P200/pc & & 400.00 \\
\hline 2 pcs shovel @ P255/pc & & 510.00 \\
\hline Sub - total & & 16.197 .51 \\
\hline Labor & Man-day & \\
\hline General \& ring weeding $(3 \mathrm{x} / \mathrm{yr})$ & 12 & $1,080.00$ \\
\hline Fertilization & 12 & $1,080.00$ \\
\hline Spraying insecticide (2x/yr) & 4 & 360.00 \\
\hline Ubod cutting (5.8 min/tree@P.19/min) & & 409.55 \\
\hline Sub-total & & $2,929.55$ \\
\hline Grand total cost (double planting) & & $19,127.06$ \\
\hline \multicolumn{3}{|l|}{ Year 4} \\
\hline \multicolumn{3}{|l|}{ Materials } \\
\hline 935 kg (18.6bags) Ammosul@P4.29/kg) & & $4,011.15$ \\
\hline 1006 kg (20 bags) $\mathrm{NaCl} @ \mathrm{P} 4.13 / \mathrm{kg}$ & & $4,154.78$ \\
\hline Sub-total & & $8,165.93$ \\
\hline Labor & Man-day & \\
\hline General weeding (ring \& under brushing 3x/yr & 12 & $1,080.00$ \\
\hline Fertilization & 6 & 540.00 \\
\hline Spraying insecticide 1x/yr & 2 & 180.00 \\
\hline Cutting of $u b o d(5.8 \mathrm{~min} /$ tree@ $@ \mathrm{P} .19 / \mathrm{min})$ & & 409.55 \\
\hline Sub-total & & $2,209.55$ \\
\hline Grand total cost (double planting) & & $10,375.48$ \\
\hline \multicolumn{3}{|l|}{ Copra production of bearing palms per hectare } \\
\hline \multicolumn{3}{|l|}{ Materials } \\
\hline \multicolumn{3}{|l|}{2 sets harvesting poles @P170/set } \\
\hline \multicolumn{3}{|l|}{4.3 bags Ammosul (215 kg)@3.90/kg } \\
\hline \multicolumn{3}{|l|}{4.9 bags $(\mathrm{NaCl}(243.1 \mathrm{~kg}) @ \mathrm{P} 3.75 / \mathrm{kg}$} \\
\hline \multicolumn{3}{|l|}{4 pcs scythes for weeding at P180/yr } \\
\hline \multicolumn{3}{|l|}{3 pcs grub hoes for fork in at $\mathrm{P} 180 / \mathrm{pc}$} \\
\hline \multirow{2}{*}{\multicolumn{3}{|c|}{$\begin{array}{l}2 \text { pcs bolos } @ \text { P180/pc } \\
1 \text { unit weighing scale }(25 \mathrm{~kg} \text { cap }) @ \mathrm{P} 1,300\end{array}$}} \\
\hline & & \\
\hline Labor & No. of Man-day & \\
\hline General weeding $(3 \mathrm{x} / \mathrm{yr})$ & 12 & \\
\hline Fertilization $(2 \mathrm{x} / \mathrm{yr})$ & 8 & \\
\hline $\begin{array}{l}\text { Harvesting, hauling \& copra making ( } 20 \% \text { of } \\
\text { copra value) }\end{array}$ & 10 & \\
\hline & & \\
\hline & & \\
\hline & & \\
\hline
\end{tabular}


